\title{
The Place of Politics in Social Protection Program: Focus on Infant and Maternal Health Care Delivery in Akure, Nigeria
}

\author{
OLORUNFEMI, Samuel Oluwaseyi ${ }^{1}$ \\ Department of Transport Management Technology \\ Federal University of Technology Akure, Nigeria \\ LAWAL, Olubunmi Lukman ${ }^{2}$ \\ Centre for Continuing Education \\ Federal University of Technology Akure, Nigeria
}

\begin{abstract}
The study examines the place of politics in infant and maternal health care delivery in Akure. To achieve this, the following objectives were made: assess the magnitude of infant birth and death as well as maternal death in the study area from 2003-2017, identify the causes of infant and maternal death in Akure, examine the relationship between politics and infant and maternal health care through policies and programmes instituted by various administrations and identify challenges facing infant and maternal health care delivery in Akure. To successfully capture these objectives, two governments owned hospitals (Mother and Child Hospital and Ondo State Specialist Hospital Akure) were selected for the administration of questionnaires. In all, eighty (80) women that have made use of the hospitals during pregnancy and child care stage were randomly and purposefully selected from the record file of the hospitals for the purpose of questionnaire administration. Likewise, the Chief Medical Directors of the two hospitals were interviewed. Data obtained were collated and presented using the descriptive statistical method. Findings revealed the policies, programmes, and accomplishments of successive governments of Ondo State from 2003-2017. The study recommends that successive government at all levels irrespective of political or party affiliation should make infant and maternal health care free most especially to the poor and the vulnerable group in the society.
\end{abstract}

Keywords: Politics, Infant, Maternal, Health Care, Akure.

\subsection{Introduction}

The place of politics in the sustenance of social protection program cannot be over emphasized; in fact, its position in the place of infant and maternal health care delivery cannot be ignored. This is because Social protection programmes tackle multiple dimensions of poverty and deprivation such as education, health care, food security, income, security and soon (United Nation, 2012). It has also been recognized as a powerful tool in the battle against poverty and inequality. According to Handset al, (2011), social protection programmes are a fundamental level of interventions by the public, private and voluntary organizations and informal networks that are planned to support individuals, households, and communities in efforts to prevent, manage and overcome risks and vulnerabilities. Social protection can play a fundamental role in creating more inclusive and sustainable development pathways. In the absence of social protection, people, especially the most vulnerable, are subjected to increased risks of sinking below the poverty line or remaining trapped in poverty for generations (United Nation, 2012) 
Social protection agenda across Africa have gained increasingly significant political attention over the last decade, as governments pursuing the MDGs and other development initiatives that have sought to reduce population vulnerabilities in the face of emerging global challenges, shifting demographic patterns, and persistent drivers of inequality and exclusion (Ortiz et al., 2010). These multi-dimensional vulnerabilities impact children in ways to which social protection policy and programming must remain particularly sensitive, given the impacts that child deprivation can have not only in the present but across children's life-courses and inter-generationally (Jones and Holmes, 2010). Despite a large expansion of schemes in developing countries, existing social protection policies do not sufficiently address the income security needs of children, particularly in low- and middle-income countries with a large child population. About 18,000 children die every day, mainly from preventable causes; many of these deaths could be avoided through adequate social protection (International Labour Organization, 2015).

Corroborating the above, United Nation (2012) opined that about $80 \%$ of the global population has no access to comprehensive social protection. Globally, social protection programmes have been formed to better the lives of people in several areas such as maternal health care, education, nutrition, and environmental health, etc. (United Nation, 2012). In the context of this research, emphasis will be placed on infant and maternal health care delivery.

The issues of infant and maternal health care delivery fall within the purview of social protection programme that bordered on issues of vulnerabilities. This according to Babken and Jessical (2010) related to life course cycle (such as maternity and old-age); physical inability to work or to be productive as a result of disability, injury or illness. The health of mothers, newborns, and children is currently the focus of the agendas of multilateral organizations, international cooperation agencies, and governments around the world and the importance is reflected in the Millennium Development Goals which express the historic consensus of the international community as to which high-priority challenges must be faced to improve the quality of life of people around the world and achieve sustainable development (Pan American Health Organization, 2008).

The utilization of maternal health care in sustaining child survival and reducing maternal morbidity and mortality has been long recognized (Ikamari, 2004).) In 1987, the Safe Motherhood Initiative (SMI) was launched to bring attention to the 'neglected tragedy' of maternal mortality (Katerini and Dominique, 2016). Equally, in 2005, the Partnership for Maternal, Newborn and Child Health (PMNCH) was formed at the 'Lives in the Balance' meeting in New Delhi to bring maternal and child initiatives back together. Its mission was 'to support the global health community to work successfully towards achieving MDG 4 and 5' on child survival and maternal health (Katerini, and Dominique, 2016). Despite the intervention of these programmes, infant and maternal mortality are still high most especially in developing countries. For instance, Nigeria with a population of over150million has one of the weakest health systems in the world and was ranked 187th out of 191 member states by the WHO in 2000 (Unekeet al, 2013). Due to the weak health systems, maternal and child health status in Nigeria is among the worst in Africa and has not improved substantially, and in some areas of the country, has worsened over the past decade. With approximately 2.5 percent of the world's population, Nigeria has more than 1 million newborn, infant, and child deaths and more than 50,000 maternal deaths every year (USAID 2008; Unekeet al, 2013)

Annually, an estimated of 52,900 Nigerian women lose their life from pregnancy connected complications, out of a total of 529,000 global maternal deaths, thus a woman's chance of dying from pregnancy and childbirth in Nigeria is 1 in 13 cases (Howard-Grabman, et al, (2007). Nigeria loses 2,300 under-five-year-olds and 145 women of childbearing age every day, making Nigeria the second largest contributor to the under-five and maternal mortality in the world (Unekeet al, 2013). The main causes of maternal mortality in Nigeria as noted byGalandanciet al, (2007);Unekeet al, (2013); Esan, and Fatus, (2014) include: infection, hemorrhage, unsafe abortion, obstructed labor, hypertension, Malaria, anaemia, and others including HIV and AIDS which contributes about (5\%). Many of these complications occur during pregnancy, labor, and delivery. Meanwhile, many of these problems are preventable, the coverage and quality of health care services in Nigeria continue to fail women and children due to the poor way of handling their case. Other contributing factors to infant and maternal mortality as identified by Unekeet al, (2013); Esan andFatus, (2014); Olugbamila and Adeyinka (2017) include lack of awareness or information about complications in pregnancy and on the need to seek medical intervention early; lack of transportation to the health facilities where maternal health care can be provided; inability to pay for services, poverty among others. It is therefore important that women should have access to skilled attendants at birth, as well as access to quality obstetric care. This care should not only be accessible but also affordable (Unekeet al, 2013).

In the global context, the availability of ample reproductive and child health care remains an unrealized goal in most countries of the world, and some nations have actually experienced stagnation or even reversals in their maternal and child health indicators. This reality has urged policymakers and international cooperation agencies to focus on the implementation of different mother, newborn and child health protection schemes in order to improve access to care for these populations (Pan American Health Organization, 2008). 
Akure is the capital city of Ondo state and it has housed four democratic governors from 1999 when Nigeria change from military system of government to a democratic system of government till date. The issues of infant and maternal health care delivery is an important issue to the government of Ondo state right from the inception of the democratic era in the state till date but the concern of each of the tenure of the government to the infant and maternal healthcare differ from each other. It is against this background that this study seeks to assess the place of Politics in Social Protection Program in Akure with emphasis on Infant and Maternal Health Care Delivery from 2003 to 2017 while the objectives are: (1) assess the magnitude of infant birth/death and maternal death in the study area from 2003-2017; (2) identify the causes of infant and maternal death in Akure; (3)examine the relationship between politics and infant and maternal health care through policies and programmes instituted by various administrations; and (4) identify challenges facing infant and maternal health care delivery.

\subsection{Literature Review}

According to Garcia andGruat (2003), the presence of social protection can be recognized as one of the most significant social achievements of the 20th century. The authors further noted that the Systems of social protection allow societies to advance the well-being and security of their citizens by protecting them from vulnerability and deprivation in order to have a decent life. Social protection can as well meet the essential needs of human survival by ensuring that all men and women have basic social and economic security. At the same time, it can play a more far-reaching role in enhancing the quality of life of individuals and societies by developing and unleashing human potential, facilitating structural change, increasing stability, advancing social justice and cohesion, sustain a healthy life and promoting economic dynamism.

United Nation (2012) opined that Social protection programmes are a powerful tool in battling poverty, vulnerability, and inequality as they can tackle multiple dimensions of poverty and exclusion. Social protection should ensure that all people have access to essential goods and services, removing social and economic barriers to access, and therefore is an important means to foster equality and social solidarity in a society. Social protection can play a fundamental role in creating more inclusive and sustainable development pathways by liberating people from the fear of poverty and privations and by helping to break the inter-generational cycle of poverty. It not only tackles income poverty but also provides an effective, tangible and direct conduit to maximize human development objectives, including better nutrition, health, and education outcomes. Jones et al, (2009) revealed social protection programs to include the following:

> Social assistance to extremely poor individuals and households. This typically involves regular, predictable transfers (cash or in-kind, including fee waivers) from governments and non-governmental entities to individuals or households aimed at reducing poverty and vulnerability, increasing access to basic services and promoting asset accumulation.

$>$ Social welfare services to groups who need special care or would otherwise be denied access to basic services based on particular social (rather than economic) characteristics. Services are normally targeted at those who have experienced illness, death of a family breadwinner/caregiver, an accident or natural disaster; who suffers from a disability, familial or extra-familial violence or family breakdown; or who are war veterans or refugees.

$>$ Social insurance to protect people against the risks and consequences of livelihood, health, and other shocks. Social insurance supports access to services in times of need, and typically takes the form of subsidized risk-pooling mechanisms, with potential contribution payment exemptions for the poor.

$>$ Social equity measures to protect people against social risks such as discrimination or abuse. These can include anti-discrimination legislation (in terms of access to property, credit, assets, services) as well as affirmative action measures to attempt to redress past patterns of discrimination.

Despite the functions and benefits of social protection programs as stated above, Jones et al, (2009) further noted that there are Institutional and organizational constraints holding back the expansion of some programmes, and weak interagency coordination making it difficult to ensure the effective complementarity and success of programmes. For instance, Holmes et al, (2011) observed that in the context of high levels of poverty and inequality, Nigeria's existing social protection approach faces a number of significant challenges. The basic challenges include low coverage of existing programmes which only reach a fraction of the poor, poor implementation, fragmentation of approaches and projects across the country. Each state in Nigeria has been given the responsibility for expanding interventions through the Conditional Grants Scheme (CGS), which requires them to match federal expenditure. Having the understanding that state budgets are contracting, only a third of all states have committed to co-funding the COPE (in care of the poor)programme, and coverage is estimated at less than $0.001 \%$ of the poor. Low coverage of existing programmes, coupled with low transfer values and short programme participation (COPE beneficiaries 
receive support for one year only), restricts the potential effectiveness of social protection to address poverty and vulnerability.

In the context of health care delivery in Nigeria, the foremost challenges affecting health care delivery in Nigeria to include: inadequate decentralization of services (and the separation of responsibilities for provision of health care among the country's three tiers of government); dilapidated health infrastructure (buildings and equipment); and weak institutional capacity (no effective system for supervision of health services in the public and private sectors). Where there is service delivery, it is hugely over-subscribed most especially in urban centers. In 2003, as reported by Rural Poverty Portal (2010) there were 0.3 physicians per 1,000 people. This implies that traditional medicine still plays an important role in meeting the health needs of the population (Antai, 2010).

A number of factors have been noted to affect the demand for accessing health care services. First, the introduction of fees has had a negative impact. For instance, in the study of Holmes et al,(2011), it was revealed that $46 \%$ decline in the number of deliveries at the main hospital in the Zaria region as a result of the introduction of user fees. Second, low-quality health care providers such as inadequate of basic equipment and medicine and competent staff also affect health-seeking behaviors. Third, social and cultural norms, as well as gender inequality, play an important role. For example, almost $75 \%$ of married women in the lowest wealth quintile do not make their own decisions with regard to their own health care, varying from around $80 \%$ in the North West (not disaggregated by wealth quintile) to around 30\% in the South West (NPC and ICF Macro, 2009). Other impediment factors in accessing health care service in Nigeria as noted by Holmes et al, (2011) also include lack of information, fear of side-effects and mothers' educational attainments it influences the coverage of child immunizations.

It is interesting to note that several authors and researchers had devoted time and energy to study issues about social protection program in relation to infant and maternity health care deliver universally. For instance, Olatunji (2013) looks at the public policy as a dividend of democracy using 'Abiye Safe Motherhood programme in Ondo State, Nigeria. The author sees the "Abiye Safe Motherhood programme as a kind of social protection program designed to safe child and mother during pregnancy, delivery period and post-delivery period. The author relied on existing literature for the study and find out that the "Abiye Safe Motherhood programme in Ondo state succeeded in reducing maternal mortality rate but failed to provide concrete information on the infant mortality rate. The author also failed to explain the process taken to achieve such success. The author recommends that public-private partnership should be encouraged in 'Abiye Safe Motherhood programme to further sustain the programme.

Ikamari (2004) studied maternal health care utilization in Teso District, Kenya. The author used descriptive statistic to present the data and the findings showed that most of the respondents in the study area are aware of the importance of antenatal visit, majority seek antenatal care at a very late stage in pregnancy and most of their childbirth takes place at home due to lack of access to institutionalized care; quick means of transport, inability to meet user charge and associated costs. However, the author failed to provide empirical evidence of number morbidity and mortality rate in the study area.

Esan and Fatusi (2004) studied the Performance Needs Assessment of Maternal and Newborn Health Service Delivery in Urban and Rural areas of Osun State, South-West, Nigeria. The study considered 14 urban and 10 rural-based randomly selected PHC facilities. Using a Performance Needs Assessment framework, desired performances were determined by key stakeholders and actual performances measured by conducting facility survey. Chi-square tests were used to determine the Performance gaps for the urban and rural areas and compared. Findings revealed that PHC facilities and health workers in Osun State, Nigeria, were found to have significant gaps in MNH service performance and this was worse in the rural areas. The author noted that the root cause of most of the performance gaps was due to the poor political will of local government authorities. The author recommended that improved government commitment to $\mathrm{MNH}$ is needful to address most of the gaps. Yet, the author failed to information on the variation of government support to $\mathrm{MNH}$ in the political dispensation of the study area.

The gap in the literature reviewed above remains the major task that the study needs to fill in order to add to existing literature and body of knowledge.

\subsection{Study Area}

Akure is the administrative capital of Ondo State since 1976 and is situated on latitude $7^{\circ} 17^{\prime} \mathrm{N}$ and longitude $5^{\circ} 4^{\prime} \mathrm{E}$ of the Greenwich Meridian. It is about $370 \mathrm{~m}$ above the mean sea level. It is positioned within a 48 kilometer radius to major towns in Ondo State which are Ondo to the South, Owo to the East and Iju/ItaOgbolu to the North. The area towards Ado - Ekiti and Idanre are hilly and studded with large granite formation, rising to 410 meters and 496 meters above sea level respectively (Olamiju and Oyinloye,2015)

The easy access and geographical centrality of Akure to nearby towns such as Ondo, Owo, Ilesa, and AdoEkiti., have enhanced the growth prospects of the city. The influx of people into the town was necessitated by the development attracted to Akure as a state capital. With the presence of government seat in Akure, job opportunities, 
provision of community and social facilities enhanced the migration of youths from the surrounding towns/settlements for job opportunities resulting in rapid population increase. Akure has two notable government hospitals namely: State Specialist hospital and Mother and Child Hospital.

According to the 1991 census, the population of Akure was 239,124 and was projected by the National Census Board to 269,207 in 1996. In 2006, the population had increased to 3,441,024 with 1,761,263 male and $1,679,761$ female, which represent $2.46 \%$ of the total population of Nigeria. The current estimated population of Akure at the annual growth rate of 3.18 is 413,060 (National Population Census, 2006).

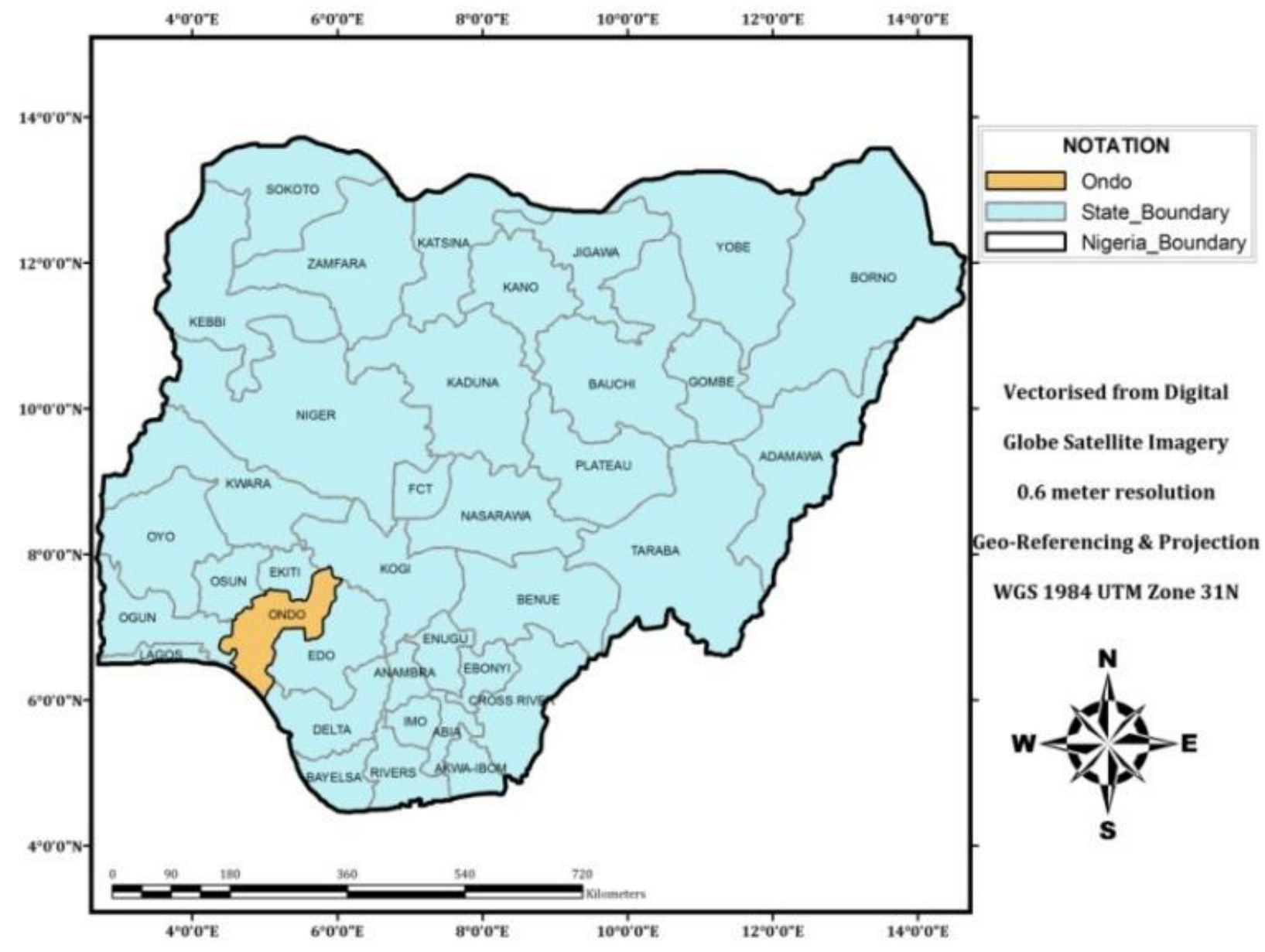

Source: Adapted fromOlamiju and Oyinloye (2015) 


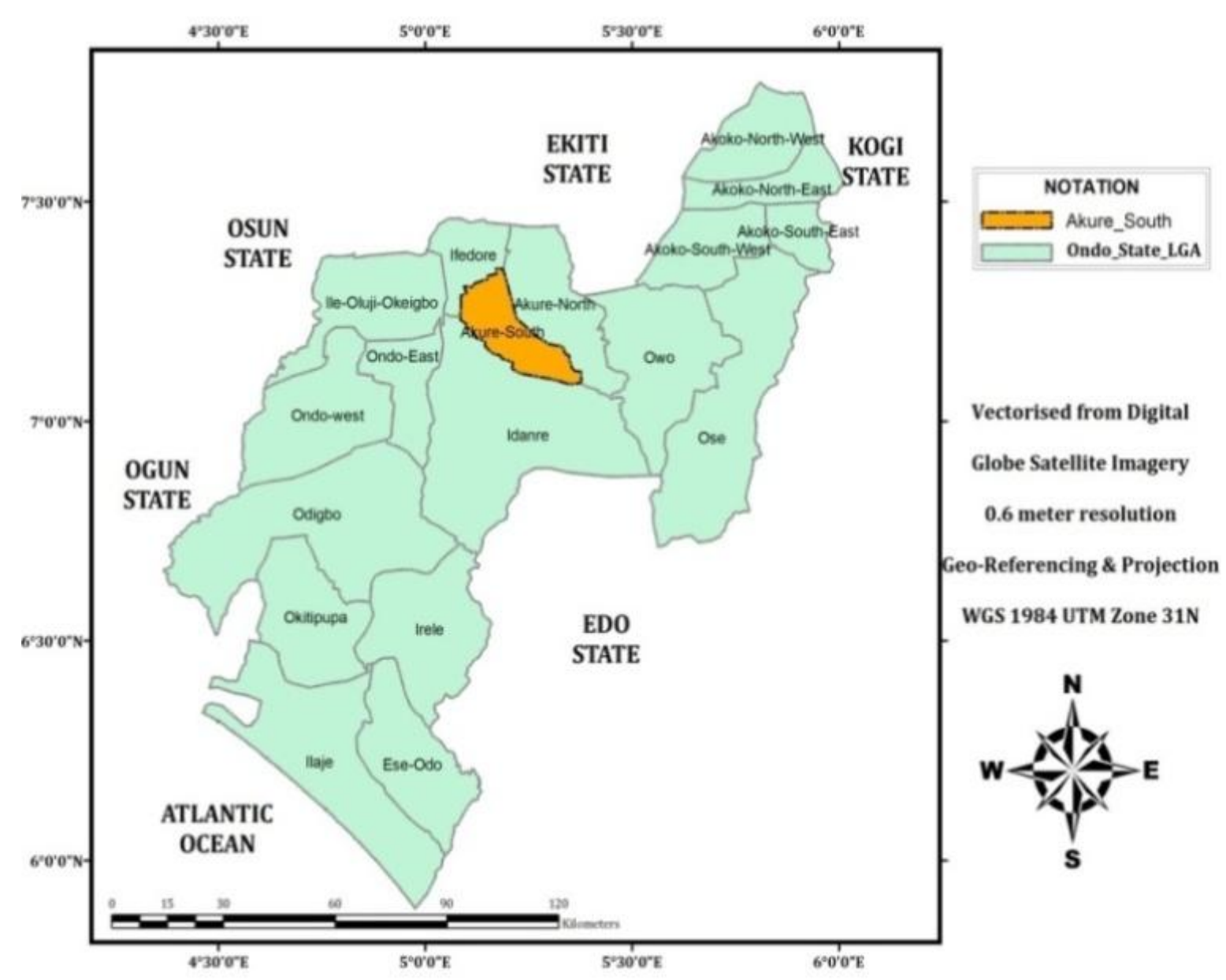

Source: Adapted fromOlamiju andOyinloye (2015)

\subsection{Research Methodology}

The study made use of the survey approach to collect data for the achievement of its objectives. Majority of the data for the study were sourced using primary techniques of data collection involving questionnaire administration. Desk research was also used to gather relevant information from the literature

In the course of this research, eighty (80) respondents (Mothers) that have made use of Ondo State specialist hospital and Mother and Child Hospital, Akure were randomly and purposefully selected for the purpose of questionnaire administration from the record file of the hospitals. The purposive sampling is to ensure that only mothers that are registered with the Ondo State specialist hospital and Mother and Child Hospital, Akurewere surveyed. The random technique is to ensure that individual mother has equal rights to be sampled for the purpose of the study. The proportions of the respondents selected area reasonable, considering the regularity of demand pattern for services in the hospital. Data collected were analyzed using descriptive statistics in the form of frequency and percentages. Equally, relevant information was sourced from the Chief Medical Director of Ondo state specialist hospital and Mother and Child hospital Akure.

\subsection{Results and Discussion}

\subsection{General Socio-Economic Characteristics of Respondents}

The analysis in Table 2 shows the summary of the socio-economic characteristics of the respondents who were surveyed for the study. The variables examined include the respondents' age, educational status, household size, and income. The age of the respondent revealed that $37.00 \%$ of them fall within the age bracket of 18-30 years, $45.0 \%$ were within $31-45$ years and $19.00 \%$ were discovered to be 45 years and above. This shows that the majority of the respondents (mothers) in the study area fall within the age of 31-45 years. The educational status of the respondents in the study shows that $6.00 \%$ had no formal education, $11.00 \%$ possessed primary school education while $28.00 \%$ had secondary education and $48.00 \%$ acquired tertiary education. This indicates that the majority of 
respondents are well educated and that has awareness about the utilization of hospital for proper infant and maternal care services. No wonder it is noted by Türkkahraman (2012) that education is a light that can create a safer, healthier and enhance the living standard of people by changing the vision and perspectives of the individual.

The figure on a household size of the respondents shows that $11.00 \%$ of them have 1-2 household size, $25.00 \%$ have 2-3 household size while $23.00 \%$ have 3-4 and $41 \%$ have a household size of 4 and above. This shows that majority of the respondents have a household size of 4 and above. It was also discovered from the analysis in the Table 2 that $6.00 \%$ of the respondents received $\$ 100,001-200,000,11.00 \%$ claimed to receive $\$ 200,001$ $\$ 300,000,28.00 \%$ affirmed $\$ 300,001-\$ 400,000$, while $31.00 \%$ earned $\$ 400,001$ - $\$ 500,000$ and $24.00 \%$ received above $\$ 500,000$ annually. The analysis shows that majority of the respondents in the study area earned between $\$ 400,001$ - $\$ 500,000$ annually. Although looking at the economic situation of the country Nigeria, this may not be enough to take of themselves and their children and such may hinder them from accessing health care services most especially where it is not provided free of charge.

Table 1: General Social -Economic Characteristics of Respondents

\begin{tabular}{|c|c|c|c|}
\hline & Social Economic Characteristics & Frequency & Percentage \\
\hline \multirow[t]{5}{*}{1.} & Age & & \\
\hline & 18-30 Years & 36 & 45.00 \\
\hline & 31-45 Years & 29 & 37.00 \\
\hline & 45 Years and Above & 15 & 19.00 \\
\hline & Total & 80 & 100.00 \\
\hline \multirow[t]{6}{*}{2.} & Educational Status & & \\
\hline & No Former Education & 5 & 6.00 \\
\hline & Primary School & 15 & 19.00 \\
\hline & Secondary School & 22 & 28.00 \\
\hline & Tertiary & 38 & 48.00 \\
\hline & Total & 80 & 100 \\
\hline \multirow[t]{6}{*}{3.} & Household Size & & \\
\hline & $1-2$ & 20 & 25.00 \\
\hline & $2-3$ & 33 & 41.00 \\
\hline & $3-4$ & 18 & 23.00 \\
\hline & 4 and Above & 9 & 11.00 \\
\hline & Total & 80 & 100.00 \\
\hline \multirow[t]{7}{*}{4.} & Annual Income Status & & \\
\hline & $\$ 100,001-\$ 200,000$ & 5 & 6.00 \\
\hline & $\$ 200,001-\$ 300,000$ & 9 & 11.00 \\
\hline & $\# 300,001-\# 400,000$ & 22 & 28.00 \\
\hline & $\$ 400,001-\$ 500,000$ & 25 & 31.00 \\
\hline & $\$ 500,000$ and Above & 19 & 24.00 \\
\hline & Total & 80 & 100.00 \\
\hline
\end{tabular}

Source: Authors Field Work, 2018

\subsection{Quality of Service enjoyed at the Hospital}

Quality of service enjoyed has been identified to be one of the factors that motivate customers' patronage. In order to determine the level of the quality of services enjoy in both hospitals, four (4) parameters were considered. These include the registration process at the hospital; child labor and delivery care; postnatal care; and access to drugs and vaccine. These parameters were measured on 5 points likert scale "poor", "fair", "good", "very good" and "excellent" as shown in table 2. From all indication, it is revealed from Table 2 that the registration process is undertaken at mother and Child Hospital Akure is fair with a mean value of 2.43. This implies that the hospital management needs to improve upon their registration process to ease the stress undergoes by pregnant women during the registration process. Other parameters considered (child labor and delivery care; postnatal care; and access to drugs and vaccine) were good for both hospitals (see Table 2). 
Table 2: Quality of Service enjoyed in the Hospitals

\begin{tabular}{|c|c|c|c|c|c|c|c|c|c|c|c|c|c|c|}
\hline Parameter & \multicolumn{7}{|c|}{ Mother and Child Hospital Akure } & \multicolumn{7}{|c|}{ State Specialist Hospital Akure } \\
\hline & Poor & Fair & Good & $\begin{array}{l}\text { Very } \\
\text { Good }\end{array}$ & $\begin{array}{l}\text { Excelle } \\
\mathrm{nt}\end{array}$ & $\begin{array}{l}\text { Mea } \\
n\end{array}$ & $\begin{array}{l}\text { Rema } \\
\text { rk }\end{array}$ & Poor & Fair & Good & $\begin{array}{l}\text { Very } \\
\text { Good }\end{array}$ & $\begin{array}{l}\text { Excelle } \\
\text { nt }\end{array}$ & $\begin{array}{l}\text { Mea } \\
n\end{array}$ & $\begin{array}{l}\text { Remar } \\
\mathrm{k}\end{array}$ \\
\hline $\begin{array}{l}\text { Registrati } \\
\text { on } \\
\text { Process }\end{array}$ & $\begin{array}{l}6 \\
(15.0 \% \\
)\end{array}$ & $\begin{array}{l}15 \\
(37.5 \\
\%)\end{array}$ & $\begin{array}{l}15 \\
(37.5 \\
\%)\end{array}$ & $\begin{array}{l}4 \\
(10.0 \% \\
)\end{array}$ & - & 2.43 & Fair & $\begin{array}{l}8 \\
(20.0 \% \\
)\end{array}$ & $\begin{array}{l}5 \\
(12.5 \% \\
)\end{array}$ & $\begin{array}{l}20 \\
(50.0 \% \\
)\end{array}$ & $\begin{array}{l}7 \\
(17.5 \% \\
)\end{array}$ & - & 2.65 & Good \\
\hline $\begin{array}{l}\text { Child } \\
\text { labour and } \\
\text { delivery } \\
\text { care }\end{array}$ & - & $\begin{array}{l}5 \\
(12.5 \\
\%)\end{array}$ & $\begin{array}{l}23 \\
(57.5 \\
\%)\end{array}$ & $\begin{array}{l}10 \\
(5.0 \%)\end{array}$ & $\begin{array}{l}2 \\
(5.0 \%)\end{array}$ & 3.23 & Good & $\begin{array}{l}5 \\
(12.5 \% \\
)\end{array}$ & $\begin{array}{l}10 \\
(25.0 \% \\
)\end{array}$ & $\begin{array}{l}15 \\
(37.5 \% \\
)\end{array}$ & $\begin{array}{l}10 \\
(25.0 \% \\
)\end{array}$ & - & 2.75 & Good \\
\hline $\begin{array}{l}\text { Postnatal } \\
\text { care }\end{array}$ & $\begin{array}{l}2 \\
(5.0 \%)\end{array}$ & $\begin{array}{l}8 \\
(20.0 \\
\%) \\
\end{array}$ & $\begin{array}{l}25 \\
(62.5 \\
\%) \\
\end{array}$ & $\begin{array}{l}5 \\
(12.5 \% \\
\end{array}$ & - & 2.83 & Good & - & $\begin{array}{l}17 \\
(42.5 \% \\
\end{array}$ & $\begin{array}{l}23 \\
(57.5 \%\end{array}$ & - & - & 2.75 & Good \\
\hline $\begin{array}{l}\text { Access to } \\
\text { drugs and } \\
\text { vaccine }\end{array}$ & $\begin{array}{l}5 \\
(12.5 \% \\
)\end{array}$ & $\begin{array}{l}8 \\
(20.0 \\
\%)\end{array}$ & $\begin{array}{l}14 \\
(35.0 \\
\%)\end{array}$ & $\begin{array}{l}10 \\
(25.0 \% \\
)\end{array}$ & $\begin{array}{l}3 \\
(7.5 \%)\end{array}$ & 2.95 & Good & - & - & $\begin{array}{l}25 \\
(62.5 \% \\
)\end{array}$ & $\begin{array}{l}15 \\
(37.5 \% \\
)\end{array}$ & - & 3.38 & Good \\
\hline
\end{tabular}

Source: Authors Field Work, 2018

NOTE: $<1.5=($ Poor $), 1.6-2.4=($ Fair $), 2.5-3.4=($ Good $), 3.5-4.4=($ Very Good $)$ and $4.5-5.0=($ Excellence $)$

\subsection{Magnitude of Infant Birth/Death and Maternal Death}

The information received from the CMD (Chief Medical office) from State Special Hospital and Mother and Child Hospital indicated that there is equilibrium increase in the number of birth recorded in the hospitals in the year 2009 to 2015 for state specialist hospital and 2011 to 2015 for mother and child hospital. This is because maternal medical care is free of charge right from the prenatal to the postnatal stage. More importantly, the mother and child hospital was especially instituted to take care of pregnant women right from the outset to the time of delivery and their children from 0-5year after delivery. Birth rates in both hospitals decrease in the year 2016 and 2017. During this period, medical care and other ancillary services are no longer free. As such, some poor and vulnerable pregnant women, new babies and children that have been enjoying free medical services from previous administration now recourse to Traditional Birth Attendants (TBAs), trade-medical care and other less expensive orthodox means of caring for themselves and unborn baby. Corroborating the above, Holmes et al, (2011) opined that introduction of fees and low-quality health care such as inadequate basic equipment, medicine, and competent staff may have a negative impact in accessing health care services.

Table 1: Infant and Maternal records Mother and Child Hospital and State Specialist Hospital from 2009 to 2017

\begin{tabular}{|l|l|l|l|l|l|l|l|l|}
\hline & \multicolumn{3}{|c|}{ Mother and Child Hospital Akure } & \multicolumn{4}{|c|}{ State Specialist Hospital Akure } \\
\hline Year & Birth & $\begin{array}{l}\text { No of CS } \\
\text { Delivery }\end{array}$ & $\begin{array}{l}\text { No of } \\
\text { Child } \\
\text { Death }\end{array}$ & $\begin{array}{l}\text { Mother } \\
\text { Death }\end{array}$ & Birth & $\begin{array}{l}\text { No of CS } \\
\text { Delivery }\end{array}$ & $\begin{array}{l}\text { No of } \\
\text { Child } \\
\text { Death }\end{array}$ & $\begin{array}{l}\text { Mother } \\
\text { Death }\end{array}$ \\
\hline 2009 & - & - & - & - & 3346 & 480 & 147 & 5 \\
\hline 2010 & 2951 & 546 & 182 & 26 & 3206 & 527 & 114 & 2 \\
\hline 2011 & 5290 & 791 & 196 & 28 & 2120 & 319 & 87 & 1 \\
\hline 2012 & 6892 & 981 & 233 & 29 & 2622 & 346 & 77 & 7 \\
\hline 2013 & 2459 & 1271 & 192 & 15 & 2731 & 433 & 70 & 9 \\
\hline 2014 & 7257 & 1209 & 215 & 13 & 2012 & 448 & 59 & 2 \\
\hline 2015 & 7065 & 1247 & 162 & 13 & 2329 & 546 & 105 & 3 \\
\hline 2016 & 3542 & 829 & 122 & 8 & 1779 & 355 & 74 & 9 \\
\hline 2017 & 2712 & 780 & 77 & 7 & 1757 & 533 & 102 & 4 \\
\hline
\end{tabular}

Source: Mother and Child Hospital and State Specialist Hospital, Akure, 2018 
However, child and mothers death varies significantly across the year from both hospitals. Table 1 above, revealed that 147 children died in Ondo State Specialist Hospital in the year 2009. To reduce infant and maternal death in Ondo State, Ondo State government under the leadership of Dr. OlusegunMimiko established and fully empowered mother and child hospital, Akure. Despite the evolution of Mother and Child HospitalAkure and high budgetary allocation to the scheme, infant death in the hospital in the year 2012 still stands at 233 . The above led to the establishment of zero infant and maternal death policy to curb the menace in the state. Through this policy, keen considerations were given to pregnant women by organizing a seminar for them at various levels in the state to prevent child and mothers death.

\subsection{Causes of infant and maternal death in Akure and Cures}

According to Ogunjimiet al (2012) infant and maternal mortality are caused directly and indirectly. The author noted that direct causes of child and maternal may occur due to poorly funded and cultural inappropriate health and nutrition services, food insecurity, inaccurate feeding practices and lack of hygiene. The indirect causes may be less obvious externally, but play a large role in mortality statistics. For instance, female illiteracy adversely affects maternal and child survival rates and is also connected to early pregnancy. In many countries, especially where child marriage is prevalent, lack of primary education and lack of access to healthcare contribute significantly to the child and maternal mortality. In connection with the above, Saraki (2008) noted that discrimination and exclusion of access to health and nutrition services due to poverty, geographic and political marginalization are factors contributing indirectly to mortality rates.

The Chief Medical Directors of Mother and Child Hospital and State Specialist Hospital Akurerevealed causes of infant death (0-12months) to include prematurity, infections, perinatal asphyxia, and congenital abnormalities. Severe malaria, anemia, and respiratory tract infection (pneumonia) cause death in older children (15years). In a related study, Ogunjimiet al (2012) noted that 70\% of child deaths in Africa continent are attributed to preventable causes such as acute respiratory infections, diarrhea, malaria, measles, malnutrition and neonatal conditions which include suffocation, prematurity and low birth occurring alone or in combination. Both hospitals (Mother and Child and State Specialist Hospital Akure) revealed postpartum hemorrhage, eclampsia, hypertensive disorder, infections (PeuperalSepcis) and obstructed labor as causes of maternal death. Corroborating the above, (Marchie and Anyanwu, (2009); Ogunjimi et al (2012) identified the causes of maternal deaths in developing countries to include severe maternal bleeding, infections, obstructed or prolonged labor unsafe abortion, hypertensive disorders of pregnancy especially eclampsia. In State Specialist Hospital, the hypertensive disorder was identified as the major cause of maternal death while post-partum hemorrhage was identified as the major cause of maternal death in Mother and Child Hospital.

According to the CMDs of both hospitals, measures put in place to address the above causes of infant and maternal death in Akure include the use of the protocol to manage patients from antenatal to the postnatal stage, task sharing, self-audit of departments vis-a-vis mortality and morbidity reviews to know how to prevent or handle future occurrences.

\subsection{The Relationship between Politics and Infant and Maternal Health Care}

Politics remain a fundamental tool to sharpen the need of society. As a matter of fact, whatever ideology or manner in which power is secure, all governments have the responsibility not only to spell out the law, but also enforce it, and secure the state against external aggression and internal insurrection (Olugbenga, 2013). Successive governments in Ondo state came on board through the instrumentalities of politics. The extent of which they are recognized or condemned determined by their ability or inability to implement people-oriented policies. Government at all level in Nigeria embraced the millennium development goals and tackles it from different perspectives base on their party manifestos and area of know-how. For instance, to enhance infant and maternal care in Akure and reduce mortality rate amongst pregnant women and the newborn baby, the administration of Dr. OlusegunAgagu 2003-2009 occasionally introduced free drugs, free CS and health care for pregnant women and newborn baby in the State Special Hospital. Appreciable progress was made during this administration.

When Dr. OlusegunMimikocame on board 2009-2017, he consolidated on the achievements made by the previous administration by introducing zero infant and maternal death policy, partnering with World Bank and established a novel hospital called Mother and Child Hospital in Akure specifically designed for pregnant women and a newborn baby of age 0-5 years. In this hospital, pregnant women and their newborn baby are treated free of charge. Also, pregnant women with complicated issues are encouraged to undergo Caesarian Sections (CS) free of charge. The hospital witnessed an influx of pregnant women because of the free medical care in operations leaving only the financially buoyant ones to attend private and state specialist hospitals. To complement Mother and Child Hospital, Abiye Safe Motherhood programmes were introduced in the neighboring environs. The above policies led 
to a remarkable increase in birth rate and a drastic reduction in infant and maternal death. After a successful eightyear reign, barrister OluwarotimiAkerodolu came on board in the year 2017and upturned free medical services instituted by the previous administration. All medical care from antenatal to post-natal stage previously rendered free of charge at Mother and Child HospitalAkure are now paid for by pregnant women. Recently, a new-born baby delivered through Caesarian Section (CS)and her mother were detained for three weeks (November16-December 10, 2017) at the Mother and ChildHospitalAkure, over the inability of their family to offset $\$ 40,000$ (\$111) hospital bill (Okeowo, 2017). They were only released after the news went viral and some philanthropist came to their rescue.

The above amongst others clearly shows that different principal actors in the health sector play politics to enhance or weaken infant and maternal health care. From the three dispensations investigated, Dr. OlusegunAgagu contributed significantly to infant and maternal health care in Akure and its environs. His achievements were sustained and substantially improved on by the administration of Dr. OlusegunMimiko. Because of his giant strides in the health sector, Ondo state was recognized as one of the states in Nigeria with the lowest infant and maternal mortality. Attestations to this were several local and international awards won by the state government. (Muanya, 2016)Both CMDs agreed that Dr. OlusegunMimiko paid more attention to Mother and Child Hospital Akure than State Specialist Hospital Akure during his tenure. The incumbent governor Barrister OluwarotimiAkerodoluhas is not come up with any policy to show plans to either sustain the gains inherited in the health sector or surpass the legacy of his predecessor.

\section{5 Challenges facing infant and maternal health care delivery}

Several factors were identified to be inhibiting seamless infant and maternal health care in both hospitals. These are an incessant power outage, shortage of medical personnel and modern medical facilities. According to the management of Mother and Child Hospital, the hospital could no longer maintain its big generator, thereby relying on the solar system donated by the World Health Organization (WHO). The solar could only power areas like nursery and theatre. The critical areas are sometimes powered by a smaller generator. They spend as much as N130,000 on diesel in three days. The mounting debts in the hospitals especially the Mother and Child Hospitals have made the government review its free health policy leading to casualties among the poor and vulnerable citizens of the state (Okeowo, 2017).

According to the CMD of Mother and Child Hospital Akure, since the economic downturn began, the government was unable to pay contractors for the drugs and cesarean packs purchased from them. The hospital owed its contractors 26 million for the 2016 supplies. Also since the beginning of the year 2017, the government had not given subvention to the hospital, making the hospital to rely on patients for its sustenance (Trump, 2017). Also, the commissioner for health under the leadership ofGovernor OluwarotimiAkerodolupaid a courtesy or working visit to the State Specialist Hospital Akurein 2017 and observed that the hospital is congested owing to increasing patronage and economic hardship driving people away from private hospitals to government-owned ones (Vanguard Newspaper, 2017).

\subsection{Conclusion and Recommendation}

The success or failure of a society is centered on how principal actors utilize politics to administer society. Government, the principal stakeholder in the society is constitutionally empowered to meet the needs and aspirations of the citizens. Notable amongst which is the provision of quality health care for pregnant women and the baby which is the central focus of this research. The research carefully examines the place of politics (the art of government and activities of the state or process through which desired outcomes are achieved in the production, distribution, and use of scarce resources in society) in infant and maternal health care in Akure. The administration of past and present governors of Ondo State from 2003-2017 in terms of their policies, programmes, pitfalls and achievements as it relates to infant and maternal care were assessed using State Specialist Hospital and Mother and Child Hospital Akure as a case study.

The study amongst others revealed that the quality of service enjoyed at mother and child hospital in term of the registration process is fair and other parameters considered for quality service enjoyed for both hospitals (mother and child and state specialist hospital are good. Dr. OlusegunAgagu (2003-2009) introduced various policies measures at State Specialist Hospital Akure that relatively enhance infant and maternal care and reduce the mortality rate among pregnant women and newborn baby. The administration of Dr. OlusegunMimiko(2009-2017) made the health sector the center focus of his administration. In a bid to consolidate on the achievements of his predecessor, Mother and Child Hospital Akureequipped with modern medical facilities and competent professionals designed to treat pregnant women and a newborn baby of age 0-5years free of charge as established in the year 2009 to complement the existing State Specialist Hospital Akure. The free health policy made most pregnant women 
especially the poor and the vulnerable ones from Akure and Neighbouring towns and village prefer mother and Child hospital than the state specialist hospital.

The increased patronage of the Mother and Child Hospital by pregnant women and newborn baby from all walks of life made the facilities to be overstretched. Notwithstanding, Ondo State was recognized during this period as one of the states with low infant and maternal death rate in Nigeria(Muanya, 2016). Barrister OluwarotimiAkerodolu came on board in 2017 when Nigeria was at the peak of the recession. In view of this, he abrogated the free medical policy in operations in Mother and Child Hospitals. The poor and vulnerable pregnant women that gave birth in the hospital without paying were detained and made to pay before they are released. This stringent measure made some of them recourse to traditional birth attendants and other orthodox means of health care. A cursory look at the data obtained revealed that the number of babies given birth to in Mother and Child hospital has reduced drastically to two thousand seven hundred and twelve (2712) in the year 2017.

Based on the above, the following recommendations were made: successive government at all levels regardless of political or party attachment should make infant and maternal health care free most especially to the poor and the vulnerable group in the society. The above implies that they should always try to build on the successes of their predecessors irrespective of political differences. This can be achieved through an act of parliament that would make infant and maternal care a continuum. Also, both hospitals should be developed side by side; one should not be developed at the expense of others. Doing this will discourage lopsided concentrations of infants and pregnant women in one hospital. World Bank and other International Donors should come to the aid of the Ondo State Government by providing drugs, modern medical facilities, and machinery deficient in both hospitals to further sustain their operations. In all, the successive government should engage in constructive and highly developmental politics to sustainably advance infant and maternal care in Akure and its environs.

\subsection{Acknowledgment}

The authors are grateful unto the mothers that were sampled as well as the Chief Medical Director of Mother and Child Hospital and State Specialist Hospital, Akure respectively for providing relevant information for the study.

\section{References}

[1]. Antai, D. (2010).Social Context, Social Position and Child Survival: Social Determinants of Child Health Inequalities in Nigeria'. Published by Department of Epidemiology, University of Stockholm.

[2]. Babken, B and Jessical, H.Z, (2010)Social protection and social exclusion: an analytical framework to assess the links. Published by The Overseas Development Institute retrievedwww.odi.org.uk

[3]. Esan, O.T and Fatus,A.O (2014)Performance Needs Assessment of Maternal and Newborn Health Service Delivery in Urban and Rural areas of Osun State, South-West, Nigeria.African Journal of Reproductive Health 18(2): 105-116

[4]. Garcia, A.B and Gruat, J, V (2003). A Life Cycle Continuum Investment for Social Justice, Poverty Reduction and Sustainable Development. Published By International Labour Office, Geneva

[5]. Galandanci H, Ejembi C, Iliyasu Z, Alagh B, Umar U. (2007). Maternal health in Northern Nigeria —a far cry from ideal.BJOG 2007(114):448-452

[6]. Handa, H., Devereux, S. and Webb, D, eds (2011). Social Protection for Africa's Children. London: Routledge.

[7]. Holmes,R., Akinrimis,B., Morgan,J and Buck,R(2011). Social protection in Nigeria: an overview of programmes and their effectiveness. ODI Project Briefing Paper Number 59 retrieved from - Holmes, R., and Akinrimisi, B. with Morgan, J. and Buck, R. (2012) __Social Protection in Nigeria: Mapping Programmes and Their Effectiveness'. ODI/UNICEF Nigeria.

[8]. Howard-Grabman, et al (2007): Demystifying community mobilisation: an effective strategy to improve maternal and newborn health. Retrieved from [http://pdf.usaid.gov/pdf_docs/PNADI338.pdf] on $26^{\text {th }}$ January, 2018

[9]. Ikamari, L.D.E (2004). Maternal Health Care Utilization in Teso District.Afr J Health Sci2004(11):21-32

[10]. International Labour Organization (2015):Social Protection Policy Papers (Paper14): Social protection for children: Key policy trends and statistics. Published by Social Protection Department, International Labour Organization, Switzerland

[11].Jones, N. W. Ahadzie and Doh,D (2009). Social Protection and Children: Opportunities and Challenges in Ghana. Published By Unicef Ghana

[12].Jones, N. and Holmes, R. (2010). 'Gender-sensitive Social Protection and the MDGs'.ODI Briefing Paper 61. London: Overseas Development Institute (ODI).

[13].Katerini, T. S and Dominique, P. B (2016).Lives in the balance": The politics of integration in the Partnership for Maternal, Newborn and Child Health. Health Policy and Planning 31(8):992-1000

[14]. Marchie CL, Ayanwu FC (2009). Relative Contributions of Socio-Cultural Variables to the Prediction of Maternal Mortality in Edo South Senatorial District, Nigeria.Afr. J. Reprod. Health, 13(2): 109-115. 
[15].Muanya, C (2016). OndoRecods 75\% Reduction in Maternal Deaths. Retrieved from the Guardian Newspaper published on $25^{\text {th }}$ February. https://m.guardian.ng/news/ondo-records-75-reduction-in-maternal-deaths/

[16]. National Planning Commission and ICF Macro (2009) Nigeria Demographic and Health Survey 2008: Key Findings. Abuja and Calverton, MD: NPC and ICF Macro. Retrieved from......

[17].NPC (2006).National Population Commission, Population of the Federal Republic of Nigeria, Analytical Report at the National Level, Abuja. Published by National Population Census.

[18].Ogunjimi L.O, Ibe, R.T, and Ikorok, M. M (2012).Curbing maternal and child mortality: The Nigerian experience. International Journal of Nursing and Midwifery 4(3): 33-39

[19]. Okeowo, B. (2017). Ondo makes poor pregnant women vulnerable. New telegraph online published December 21 retrieved fromhttps://newtelegraphonline.com/2017/12/ondo-makes-poor-pregnant-women-vulnerable/ on 26th January, 2018

[20].Olamiju,I.Oand Oyinloye, M.A (2015).Characteristics and Vulnerability of Houses under Overhead High-Tension Powerline in Akure, Nigeria. World Environment Journal 5(3): 121-133

[21]. Olatunji, O.E (2013). Public Policy as Dividends of Democracy: An Appraisal of the'Abiye' Safe Motherhood Programme in Ondo State, Nigeria.Developing Country Studies . 3(8): 150-158

[22]. Olugbamila,O.B and Adeyinka, S.A (2017).Analysis of Socio-Economic Characteristics and Utilization of Healthcare Facilities in Owo Local Government Area of Ondo State, Nigeria. European Scientific Journal 13(23):377-391

[23].Olugbenga, E.O (2013)Public Policy as Dividends of Democracy: An Appraisal of the 'Abiye' Safe Motherhood Programme in Ondo State, Nigeria. Developing Country Studies 3 (8): 150-158

[24].Ortiz, I., G. Fajth, J. Yablonski, and A. Rabi (2010). 'Social Protection: Accelerating the MDGs with Equity'. UNICEF Social and Economic Policy Working Briefs, New York: UNICEF.

[25].Pan American Health Organization (2008).Social Protection in Health Schemes for Mother, Newborn and Child Populations: Lessons Learned from the Latin American Region. Published by Pan American Health Organization, Washington, D.C. USA

[26].Rural Poverty Portal (2010) _Rural Poverty in Nigeria'.Retrieved from www.ruralpovertyportal.org/web/guest/countr/home/tags/nigeria\# on $16^{\text {th }}$ January, 2018

[27].Saraki T (2008). Nigeria Maternal Health - More Than Just Reproductive Health.Retrieved on $31^{\text {st }}$ January 2018 on www.this day.allafrica.com

[28].Türkkahraman, (2012).The Role of Education in the Societal Development.Journal of Educational and Instructional Studies in the World 2 (4):38-41.

[29].Uneke, C.J, Ndukwe, C.D, Ezeoha, A.A and Urochukwu, H (2013): An Evidence-Based Policy Brief Improvement of Government's Free Maternal and Child Health Care Programme using Community-Based Participatory Interventions in Ebonyi State Nigeria. Published by Health Policy and Systems Research Project Team (Knowledge Translation Platform) Ebonyi State University, Abakaliki, Nigeria.

[30]. United Nation (2012).Social protection: A development priority in the post-2015 UN development agenda. Published by United Nation System Task Team on the Post-2015 United Nation Development Agenda.

[31].USAID (2008).Working Toward the Goal of Reducing Maternal and Child Mortality. Published by USAID Programming and Response. Washington, DC 20523

[32].Trump, F. (2017). Baby, mother detained in Ondo hospital over N40,000 bill. http://statepress.blogspot.com.ng/2017/12/baby-mother-detained-in-ondo-hospital.html

[33]. Vanguard Newspaper (2017).Ondo Govt. promises to expand Akure Specialist Hospital retrieved fromhttps://www.vanguardngr.com/2017/09/ondo-govt-promises-expand-akure-specialist-hospital/ on $16^{\text {th }}$ February, 2018 